\title{
The fulfillment of standards on child
} cares (Taman Penitipan Anak (TPA) and Taman Anak Sejahtera (TAS)) for the quality improvement of alternative care with the child protection perspective ${ }^{1}$

Rita Pranawati

Universitas Muhammadiyah Prof. Dr. HAMKA, Jakarta. Vice Chair of Indonesian Commission on Child Protection (KPAI), Indonesia

Email: rita.pranawati@uhamka.ac.id

Naswardi Naswardi

Universitas Muhammadiyah Prof. Dr. HAMKA, Jakarta, Indonesia

Email: naswardi@uhamka.ac.id

Sander Diki Zulkarnaen

Data analyst at the Indonesian Commission on Child Protection (KPAI), Indonesia

Email: sander@kpai.go.id

\section{Abstract}

The increasing need for child care in the industrialization era as alternative care on both Taman Penitipan Anak (TPA) and Taman Anak Sejahtera (TAS) match the quality and child protection perspective. This study measures the quality of child care from three aspects, namely institutional, human resources, and service programs. This study uses a quantitative method, applying questionnaires

1 This study is the result of KPAI's (Indonesian Commission on Child Protection) program on monitoring and evaluation of the child care in 9 provinces. 
interviewed and data processed using SPSS. The samples of this study are TPA and TAS in 9 provinces representing the diversity. The study found that about $44 \%$ of child care do not have a license which will affect services. The staffs have adequate quality but it is necessary to hold a selection process ensuring the child protection perspective and a good track record. Training is necessary to improve the knowledge and skills related to child protection and development. There is still 20\% of child care that needs to improve the quality.

Keywords: Child Care, Standard, Child Protection

\section{Introduction}

In the era of industrialization, people's need for alternative care such as daycare during parent working hours is increasing. The rise of women's education and participation in the labor force (Wijayanto \& Wulan Sari, 2019), the difficulty of finding, and the high cost of domestic workers who qualify as caregivers, has an impact on the increasing need for child care. Child cares, which in Indonesian law is manifested in the Taman Penitipan Anak (TPA) under the Ministry of Education and Culture and Taman Anak Sejahtera (TAS) under the Ministry of Social Affairs, are a choice of the care rights fulfillment during the parents' work. In this paper, both TPA and TAS are entitled to child care.

Parenting is a basic right of children which is the foundation for children's development. Parenting is the process of ensuring children's development and educating children (Hastuti, 2015). In the Indonesian Child Protection Act Article 7 point 1, parenting by the parents themselves is the basic right of the child. But the practice of parenting can be held by large families, grandparents, domestic workers, and sending kids to child care. KPAI's findings, $73.8 \%$ of fathers and $74.2 \%$ of mothers stated that their care was assisted by others, including child care (Pranawati et al., 2015). TPA is a substitute for the role of parents in caring, socialization, and education conducted by caregivers and educators (Kusumastuti, 2013). When there is a transfer of care, including in child care, parents should ensure that the temporary transfer of parenting also has good qualities for child protection.

The need for child cares has not been comparable yet to the standardization of quality. Child care by definition is the provision of care and education to children within a few hours when the parents work either in the form of institutions or home-based for children of different ages (Bredekamp, 
2017). In Indonesia, the rules on institutional child care exist under the Ministry of Education and Culture by Decree Number 137 of 2014 on the National Standards of Early Childhood Education. In this case, TPA becomes part of early childhood education from 0 to 6 years old. Taman Anak Sejahtera (TAS) is under the Ministry of Social Affairs stipulated in the Regulation of the Minister of Social Affairs of the Republic of Indonesia Number 2 of 2012 concerning Taman Anak Sejahtera. TAS is intended as a form of social services to provide care, parenting, and protection for children from 3 months to 8 years.

The standardization of child care services should include the perspective of child protection. The cases that occurred in Samarinda (Dharmastuti, 2019) and Bali (Mardiastuti, 2019) where the child died while in child care became an example of the importance of child care standardization. Child care performs the alternative care as long as the parents are working or unable to care. Standardization of child care is not enough only by regulating the curriculum, facilities, and infrastructure, but also developing the perspective of child protection. The child protection perspective will provide a framework for the implementation of child protection, including in the implementation of alternative care in TPA and TAS. This study will answer how the quality of TPA and TAS implementation in Indonesia, the quality of human resources organizers, and how the quality of service programs in TPA and TAS.

\section{Literature Review}

Most child care studies have not addressed child care from the child protection perspective. This literature review will discuss child development, child care studies, and daycare standards.

\section{Child Development}

Every child has a dignity that must be fulfilled his rights to well grow up. In the Ministry of Social Affairs Regulation Number 21 of 2013, parenting is an effort to meet the needs of compassion, attachment, safety, and sustainable welfare in the best interests of the child. Every child has the potential to develop regardless of their physical and intellectual circumstances (Daniel, B., Wassell, S., Gilligan, R., \& Howe, 2010).

Children's development will be greatly influenced by an assessment of their past and current conditions to reduce vulnerability and to improve child resilience. The golden age of children from birth to 6 years is an important period to receive stimulus as a process of child development both physical, 
psychic, and intellectual. The golden age is a golden phase in development that only lasts once and should receive full attention from parents (Sit, 2017).

The 0-6-year old phase has the complexity of growth and development that is important for children's development. At the age of 0-6 years, there is a period of conception until birth, babies up to 2 weeks, phases of two weeks to 2 years, early childhood to six years, and phases 6 to 12 years (Hurlock, 1996). From those child's growth phase, the child's phase occupies a very important phase, which is 4 out of five phases of growth and development. Development is not only progress but can be reversed if the development does not go well (Hurlock, 1996).

During this golden age, children experience physical development from the growth of cells and organs to the development of gross motor that produces physical abilities such as walking and fine motor such as writing. Besides, according to Bloom, up to 8 years, brain development achievement reached $80 \%$ (Sit, 2017). While socially, children learn to interact, language skills, values, and religion. While in the emotional aspect, children tend to express emotions freely and openly (Uce, 2015).

\section{Overview Child Care Studies}

Studies on daycares have focused on the aspects of health, infrastructure, communication, and language. Kusno's study (2014) discussing the linguistic modesty of teachers' and caregivers' imperative sentences to children in TPA, Krisnana et al study (2016) found that the role of caregivers' asah (3A, asah, asih, asuh, the principle of Indonesian caring) is quite strongly related to the development of children's language. Meanwhile, Azeharie and Khotimah study (2015) at TPA Melati Bengkulu, found that the primary communication through the effectiveness of interpersonal communication from teachers to students is with openness, empathy, support, and emotional attachment of teachers and students.

Maulidina and Sumartinah's study (2015) discusses narrative approaches to TPA design. Simonsen's study (2010) stated that the availability of daycare has an impact on women's work and the daycare prices negatively impact the work of mothers of children in child care, while Clark et al study (2019) the childcare subsidies have a diverse impact on marital status and across incomes and for the poor of Africa. The failure to meet women's needs for childcare has an impact on the promotion of women's economic empowerment.

Ralston's study (2020) discusses the disruption of the caregivers' gadget 
with the child welfare perspective and ethical analysis, while de Moura et al' study (2014) states that education has an effect on the Keller parenting system as well as the need for caregiver trajectories involved in childcare. While in terms of health, Tucker et al (2011)Ontario, approximately 45 percent of preschoolers are insufficiently active.With the large number of preschoolers who attend childcare (54\% study mentions the excess activity of children in child care so that curriculum revision is necessary. Geoffroy et al.'s study (2006)and elevated levels of cortisol have been implicated in the onset and development of mental health disorders. Our objective was to quantify the associations between daycare and cortisol and to identify individual and environmental conditions under which daycare attendance is associated with cortisol concentrations. Methods: We used Cohen effect size statistics to quantify these associations and to compare them across 11 published studies that were identified with MEDLINE and PsycINFO. Results: Cortisol levels increased during the daycare day, whereas they decreased when children stayed at home. The mean effect size was $d=0.72$. The magnitude of the daycare-stress relation seemed to vary under 3 specific conditions. First, the effect size was larger for children in low-quality daycare $(\mathrm{d}=1.15$ mentioned that the presence of children in daycare with lowquality conditions, in children with temperament, there can be an acceleration of atypical cortisol so that the daycare is expected to have a role to reduce mental health problems. Meanwhile, the Dodds et al study (2014)providing access to a large portion of children at a vital point in their development. Few rigorously validated measures exist to measure healthy eating and physical activity policies and practices in this setting, and no such measures exist that are specific to the childcare setting in Australia. Methods. This was a cross sectional study, comparing two measures (pen and paper survey and observation found that the value of healthy eating practices has a higher potential for kappa scores than assessments of physical activity in both policy and practice.

\section{Childcare Standard}

Daycare standards should have a license that has standards of safety, health, facilities such as clean and safe room materials according to the child, restroom, parents waiting room, and, the ratio of children and caregivers (Hikmah, 2014). Besides, the standard of daycare has trained caregivers, availability of educational game tools, and an adequate learning place (Hikmah, 2014). While Sulistyasih (2016) divides the standardization of childcare based on the reference from the Director-General of Early Education into management, learning, infrastructure, financing, and assessment. 
Some studies on daycare are conducted from a variety of points of view. Kindergartens, including childcare, in Tembalang, Semarang still does not have standard facilities (Putriana et al., 2016). The problems include the lack of officers in charge to handle and the lack of effective communication. While the study Delly, et al (2018) found that the standard operating procedure on the sterilization of milk bottles only applied at the age of 3 years, while the standard operational procedure of lunch, health services, naps, and toilet training are run well. While the study Staton et al (2019) found that $83 \%$ of registered childcare did not match 1 of 20 sleep the safety guideline targets.

Hiryanto research (2007) on the Early Childhood Education (PAUD) program, especially childcare and Play Group in Yogyakarta province, found that the implementation of 10 points on PAUD program has been implemented with all variations. The level of educational quality achievement of both the Minimum Management Standard and The Quality Standard of Educator and the Minimum Service Standards have been carried out with variations. While the supporting factor of achieving the quality of education is increasing public awareness on the importance of early childhood education and good dissemination. While the obstacles are financial problems, lack of understanding of educators about early childhood, and lack of participation in the rural communities. A study on the partnership of caregiver group and the East Java Provincial Education Office found that health services were poorly documented, there was no curriculum, and the lack of caregiver skills (Kurniawaty et al., 2019). Kusumastuti study (2013) stated that parenting is given following the basic rights of children, namely the right to live, develop, participate, and be protected, but has not elaborated how it is practiced. Meanwhile, Indrawati and Hadayani study (2014) mentioned that the parenting pattern in TPA Aisyiyah Riau is democratic.

In the technical guidelines issued by the Director of PAUD Development, there are procedures for establishment, implementation, and evaluation (Direktur Pembinaan PAUD, 2015). The principle of service is 'tempa, asah, asih, and asuh' that means the realization of good physical qualities of children, support, compassion, and the formation of good behavior and personality qualities. In terms of implementation, consists of curriculum, learning, parenting, educators, educational personnel, assessment of student development, facilities and infrastructure, management, and finance. Moreover, there is also the detection of growth, health, and nutrition services. Further, the evaluation of the program includes reporting and coaching. 
This study has constructed the childcare standards from a child protection perspective. This study will examine three aspects, namely the institutional quality, human resources, and the quality of service programs. In the institutional aspects, it will analyze institutional prerequisites including the status of operational legality, availability and quality of the organizational structure, the vision and mission, programs, and the standards operational procedures. The institutional indicator is the key of institutional quality to provide planning and pursuing child care services.

The second aspect is human resources who run the parenting process. Human resources who run services are very important to have a child protection perspective because they are the backbone of serving. The human resources consist of employees, caregivers, teachers, and accompanying teachers, administrators, and managers. Some indicators measured are human resources selection, professional support, education level, training to improve the knowledge and skill about child protection and child care implementation rules.

The third aspect of this study is the service program. This aspect portrays the recipients of service programs, the implementation of caregiving, the availability of facilities and infrastructure, services, and support. In terms of program recipients, it will analyze the demographics of the beneficiaries, the period, and the background of the placement in childcare. In the caregiving process, it will discuss the ratio of children and teachers/caregivers, and the financial aspect. The availability of facilities and infrastructure aspect will seek the building facilities and waiting rooms, playing facilities, sleeping rooms, decent toilets, food and breast milk dairy storage, and security systems. The availability of services and support includes partnerships and cooperation, sports, religious education, child and parent counseling, interest talent tests, health and immunization checks, availability of nutrition and supplementary food, availability of playgrounds, caregiving, and availability of PAUD.

\begin{tabular}{ll}
\hline INSITUTION & 1. Operational license \\
& 2. Structure \\
& 3. Vision and mission \\
& 4. Work planning \\
& $\begin{array}{l}\text { 5. Standard Operational } \\
\text { Procedure on service }\end{array}$ \\
\hline
\end{tabular}




\begin{tabular}{|c|c|c|}
\hline $\begin{array}{l}\text { HUMAN } \\
\text { RESOURCES }\end{array}$ & $\begin{array}{l}\text { 1. Selection } \\
\text { 2. Professional Staff } \\
\text { 3. Level of Education } \\
\text { 4. Professional Training } \\
\text { 5. Knowledge and Skill of } \\
\text { Child Protection and } \\
\text { Childcare }\end{array}$ & \\
\hline \multirow[t]{4}{*}{ SERVICES } & Program Beneficiaries & $\begin{array}{l}\text { Demographic Beneficiaries } \\
\text { Duration in the Child Care } \\
\text { Background of Placement }\end{array}$ \\
\hline & $\begin{array}{l}\text { Caregiving/Education } \\
\text { Process }\end{array}$ & $\begin{array}{l}\text { Teacher/Caregivers-Children } \\
\text { Ratio } \\
\text { Finance }\end{array}$ \\
\hline & Facilities and Infrastructure & $\begin{array}{l}\text { Building } \\
\text { Waiting Room } \\
\text { Playing Facilities } \\
\text { Sleeping Room } \\
\text { Toilets } \\
\text { Food and breast milk dairy } \\
\text { storage } \\
\text { Security System } \\
\end{array}$ \\
\hline & $\begin{array}{lll}\text { Services } & \text { Program and } \\
\text { Support } & & \end{array}$ & $\begin{array}{l}\text { Partnership and Cooperation } \\
\text { Sport } \\
\text { Religious Education } \\
\text { Interest Talent Test } \\
\text { Health Check and } \\
\text { Immunization } \\
\text { Nutrition and Supplementary } \\
\text { Food, } \\
\text { Kindergarten Availability } \\
\text { Caregiving }\end{array}$ \\
\hline
\end{tabular}

\section{Methods}

This study uses quantitative methods with the instruments interviewed. Sample selection is done by using purposive sampling at TPA, TAS, and a kind of childcare based on organizing, ownership, locus, and cost. The sample in the 
study consisted of 75 respondents representing 75 TPA and TAS in 9 provinces (DKI Jakarta, Aceh, Bali, Banten, DKI, West Java, West Kalimantan, Riau Islands, North Sumatra, and Yogyakarta) and 20 city districts in Indonesia. From the aspects of ownership and management, child care consists of stateowned enterprises, communities, ministries of institutions, local governments, universities, and foundations.

The survey was conducted with face-to-face interviews using questioner. Interviewers are trained to overcome bias, understand the purpose and purpose of research, understand each question in the questionnaire and have skills in the interview. Quality control applies by pre-testing the reliability of questions and training to interviewers. The data is processed using SPSS software. Furthermore, the data is cleansing and analyzed for later written results.

\section{Result and Discussion}

\section{Institution}

Fulfillment of the institutional of services prerequisites is very important for the implementation of childcare. The existence of these prerequisites is proof of the seriousness to provide alternative parenting services, namely child care. The quality of service will be determined by the readiness of the organization's devices.

Child care is legal to operate if it has legal entity documents, registration marks, or operating licenses. Without one of these permits, the agency is not yet compatible with child care services and it could violate the rule. the Study, which found that $44 \%$ of child care does not have any of the legal documents for childcare. While 30.7\% have an operational license, 13.3\% have a Legal Entity, and $12 \%$ have an agency register. The absence of legality will have an impact on the performance of childcare services that feel no need to maintain quality, not be supervised, and no need to provide the best service for child protection.

In terms of vision and mission availability, $29.3 \%$ of child care does not have one. While in terms of organizational structure, around $12 \%$ of child care does not have. Some child care does not have a mission vision to direct institutional child care. Child care has the potential to run naturally without a definite purpose. When the child care does not have an institutional structure, it will impact on overleaping tasks, the existence of tasks that are not done, up to arrangements and services that run unplanned. 
In terms of the availability of work programs, there are still $18.7 \%$ of daycare that does not have a work program. The running of childcare is potentially natural. The work program directs child care so that childcare services have clear planning and evaluation activities. Moreover, $25.3 \%$ of child care does not have standard operating procedures. Standard operational procedures provide technical guidance on the implementation of activity to comply with the rules. Whereas SOP such as breastfeeding of breast milk, if there is a sick child, if there is a child who fell, security procedure, pickup must be clear so that there are no incidents that harm the child. The cases in Bali and Samarinda are examples of the absence of SOP.

Graphic 1 Institutional Prerequisites

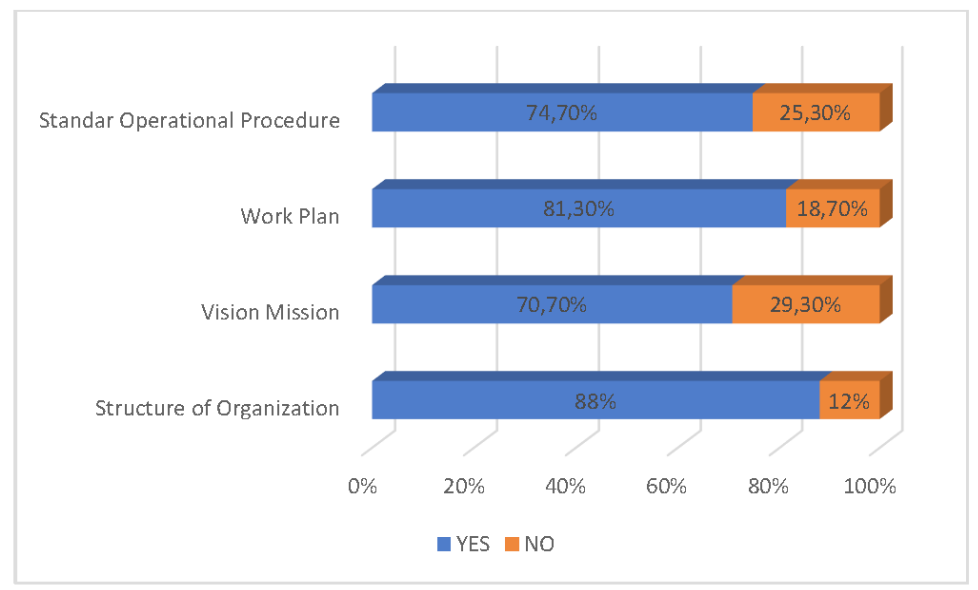

\section{Human Resources}

Human resources in the implementation of child care become one of the core keys because they are the ones who will provide services. The study found only $5 \%$ of service employees were male. The age of staff consists of 21-30 years old (37.3\%), 31-40 (33.3\%), age $41-50$ (18.7\%), age over 51 years $(8 \%)$, and age $18-20$ years and under 18 years (1.3\%). It turns out that there are still those who employ a child.

Recruitment becomes an important process in the implementation of childcare. The purpose of the recruitment is to look at the professional capacity, ensure the perspective of child protection, as well as look at its track record, whether it has ever been involved in cases of violence against children. This 
is an effort to prevent violence against children. The study found that $57 \%$ of employees were selected, namely $66 \%$ caregivers, $59 \%$ of teachers and accompanying teachers, and $62 \%$ of caregivers/managers. From this condition, it is known that there is still much childcare that does not make selections. This can certainly have an impact on the service if the human resources of the service are not selected, and it will influence the quality assurance of its services. Staff who are not selected will have an impact on the seriousness of supervising the running of childcare. Caregivers, teachers, and accompanying teachers will take care of the children immediately. While employees will support the process of running services, therefore they must still have a child protection perspective and a good track record.

Professional support is very important for childcare to run effectively. Professionals such as doctors, counselors, psychologists, social workers are necessary and they can collaborate with other parties such as local hospitals, but the services can still be provided in child care. From this study, the availability of doctors/nurses is $23 \%$, social workers and counselors respectively $16 \%$, psychologists $23 \%$, and the most are teachers at $65 \%$. The limitation of professionals can be pursued by cooperating with other parties so that there is the fulfillment of children's health rights, supervision of child development, and assistance to parents in need.

The education of the staff will also have an impact on the running of child care. Education managers or administrators as much as $49.3 \%$ are undergraduate, high school and post-graduate respectively $21.3 \%$, doctoral $(4 \%$,$) elementary and not finished elementary 1.3 \%$ and $2.7 \%$ respectively. This study shows that childcare managers are very diverse in education, from doctorate, elementary school, to not finishing elementary school. While the service employees as many as $57.3 \%$ educated undergraduate, high school as much as $40 \%$, and did not finish elementary school as much as $2.7 \%$. The small part of child care is still with the support of human resources who do not finish elementary school that still needs to be improved in the future.

The perspective of child protection and understanding of child development is very important for running child care services. Training concerning childcare, child psychology, early childhood education, and child protection is important for childcare staff to establish knowledge and skill of care, nurture, and children treatment. The knowledge and skill are part of efforts to prevent violence against children. This multiple response study found that training for implementing employees consisted of childcare (56\%), 
early childhood education (28\%), child protection (6.7\%), child psychology $1.3 \%$, and the rest of $8 \%$ has no training. From this study, it appears that the perspective of child protection must be developed to run parenting and education in childcare. The study also found that $66.7 \%$ of staff did not have a training certificate. Of $33.3 \%$ who have a certificate, those certificates are from baby sitter training which is more technical parenting and no child protection and development knowledge.

Concerning regulation, $81.3 \%$ of respondents know the Child Protection Act and $73.3 \%$ know the National Education System Law. A total of $77.3 \%$ of respondents know the Regulation of the Minister of Education and Culture Number 137 of 2014 concerning The National Standard of Early Childhood Education, while knowledge related to the rules of Taman Anak Sejahtera, respondents said that $62.7 \%$ of them understand. That knowledge is the basis for childcare running services.

\section{Services Program}

This section will explain the description of the program beneficiaries, the implementation of caregiving, facilities, infrastructure, as well as service and support programs. The study found that the largest program recipients were 2-3 years old (38.7\%), continued by $4-5$ years old (16\%), 5-6 years old and $3-4$ years old $14.7 \%$ respectively, $1-2$ years old $(10.7 \%)$, and 3.12 months $(5.3 \%)$. Besides, the most service period is more than 8 hours (46.7\%), $6-8$ hours $(37.3 \%), 4-5$ hours (14.7\%), and $1-3$ hours (1.3\%). The reason for placement in childcare is due to busy work (73.3\%), no caregivers (13.3\%), close to work (8\%), and other reasons $(53 \%)$.

In the childcare guidelines from the Ministry of Education, the ratio of caregivers aged $0-2$ is 1 caregiver to 4 children, ages $2-4$ years is 1 to 8 , and ages $4-6$ years is 1 to 15 . For $3-12$ months of age, the ratio is not ideal at $37.4 \%$, for $12-24$ months of age as much as $30.7 \%$. The age of more than 2 years is ideal in general. The lack of a caregiver-to-child ratio can have an impact on the quality of care and the potential for violence to occur in the child due to caregiver fatigue.

From this study, the ownership of child care service providers belongs to the government, foundations, and individuals. Childcare places are in private offices, government offices, factories/plantations, campuses, and housing complexes. In finance, there are $61.3 \%$ of individuals, $16 \%$ of Regional Revenue Expenditure Budget, $13.3 \%$ of foundation, $5.3 \%$, of National Budget, $2.7 \%$ 
grants, and $1.3 \%$ did not answer. The fee of service program costs $52 \%$ below one million, free at 29.3\%, $1-2$ million at $12 \%, 2-3$ million at $4 \%$, and $3-4$ million at $1.3 \%$. The fee is beyond the late pick-up penalty. Childcare demands exist ranging from all of the workplaces and housing complex and consist of childcare with a free cost because of government support, middle, to the upperclass cost.

In terms of facilities fulfillment, there is still childcare that does not have good facilities. The study found that $14.7 \%$ of childcare do not yet have a viable and adequate building. Besides, there is also no separate waiting room for child pickup which is $36 \%$. If childcare does not have a decent and adequate building, it can have an impact on the quality of childcare services, especially concerning child safety. Further, the absence of a waiting room can also have an impact on security when picking up children. In terms of special resting rooms, there are still $29.3 \%$ who do not have a resting room, while for mattress, and bed facilities, there are still $16 \%$ who do not have such facilities. The most wanted of child care services are between 6 hours to more than 8 hours. If the child care does not have a sleeping room, it will take effect on their growth.

Graphic 2 Child Care Facilities

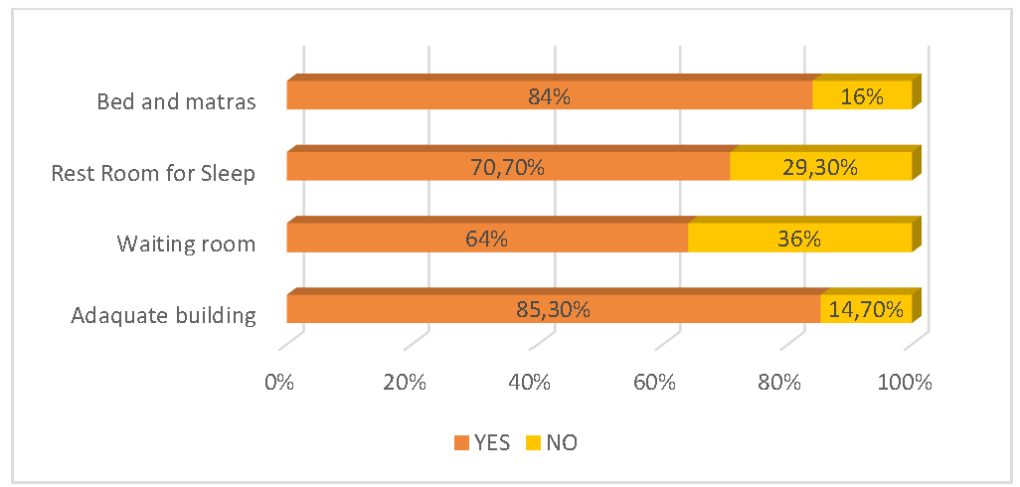

Playing facilities are very important because the age of the child is playing period. Of these studies, there were still $12 \%$ of childcare who did not have an indoor playground. Whereas indoors is needed when the air is hot or raining. Indoor playground is also areas for nurturing and learning to stimulate its growth, provide stimulus with music, movement, and other play activities. While the ownership of outdoor playground reaches $80 \%$, which means there 
is still childcare that does not have an outdoor playground. Stimulus through movements can be reduced with the absence of outdoor playgrounds. While the ownership of adequate and safe toys reached $86.7 \%$ which means there is still a small percentage of child care that does not have a decent and adequate toy for children. Nonetheless, toys are one of the important tools for children's development.

Graphic 3 Playing Facilities

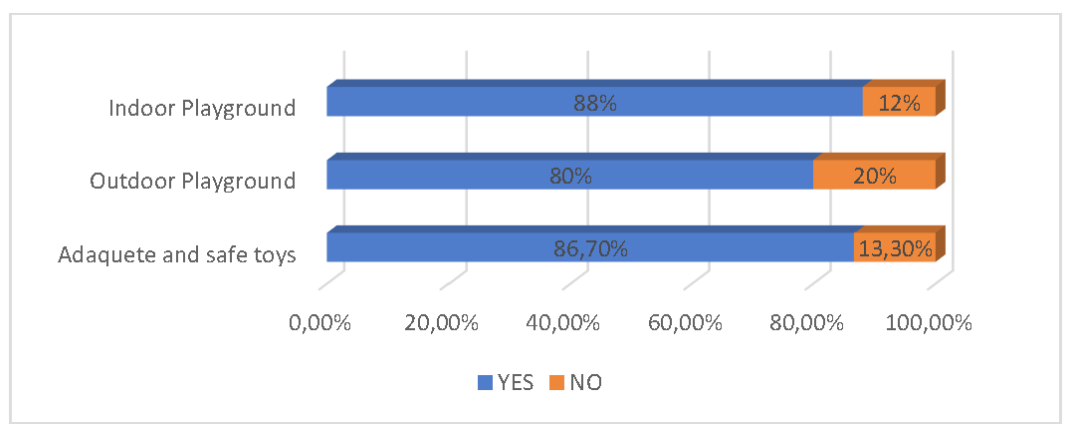

The availability of toilet facilities, breast milk and food storage, and security systems are very important in childcare services. The availability of proper and adequate toilets is at $93.3 \%$. Whereas toilets in childcare in Indonesia will be used to urinate and defecate, clean the child's body, to bathe. The facilities sometimes still use an adult perspective which the existence toilet is an adult toilet rather than a child toilet. The storage of milk and food is only $76 \%$ have it which means some childcare that has not been supported to exclusive breastfeeding and additional regarding child condition such as allergies. Only $50.7 \%$ of child care have a security system and almost the other half do not have one. This can have an impact on child safety.

Availability of essential services is prominent to support child care services. The study found that $96 \%$ provided caregiving, while the remaining $4 \%$ potentially provided only education. Nutrition and supplementary food services are available in $83 \%$ of childcare. Religious education following the religion of the child in terms of the introduction of religious practice is available in 79\% of childcare. Sports services and PAUD are at 77\% respectively and which means there are sports activities and PAUD although not in all childcare. Health screening and immunization services are available in $76 \%$ of childcare and $24 \%$ of childcare do not provide health care. Child and parent counseling 
services are only available in $61 \%$ of childcare while the rest have not provided such services. In certain cases, parenting at home is less conducive, parents do not understand basic parenting skills, so counseling is required for both children and parents. Partnerships and cooperation to improve the quality of services are paramount, for example, cooperation with health centers for health services and immunization but only $47 \%$ of childcare has partnerships and cooperation. The talent and interest test are only in $25 \%$ of childcare which is important to support their growth.

Graphic 4 Security, Stockage, and Toilet Facilities

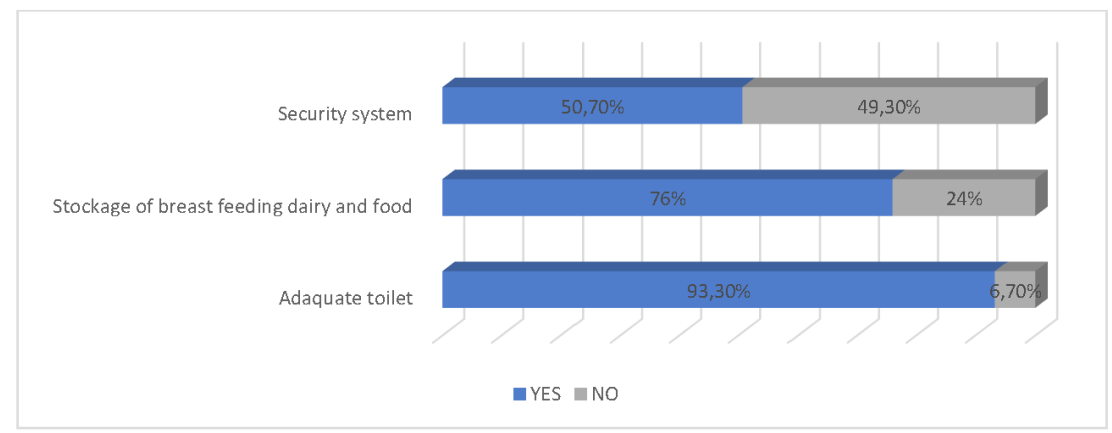

Graphic 4 Supporting Services

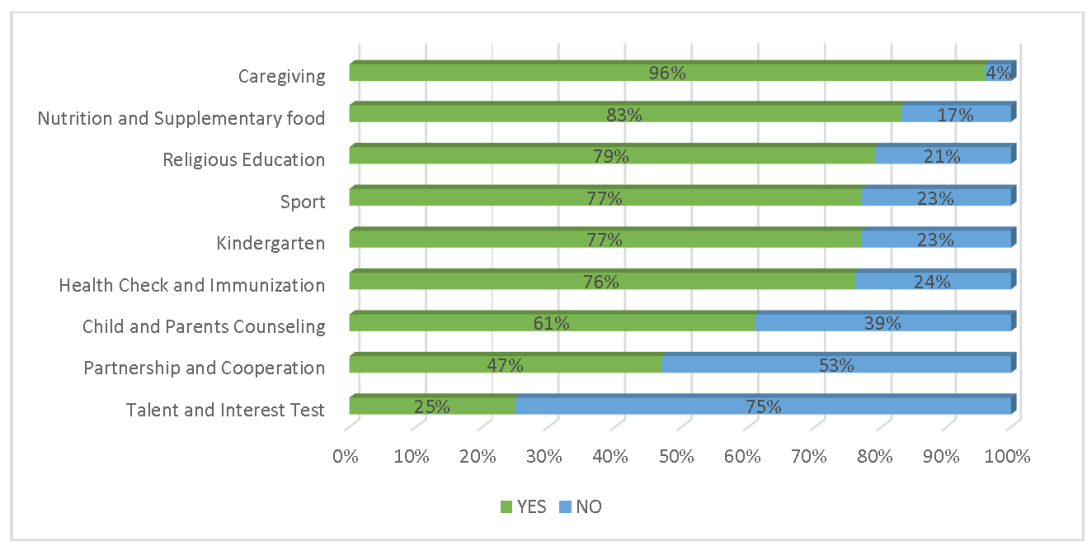

Institutional childcare still has constraints in terms of licensee, mission vision, operational standards procedures, and programs. Permit constraints are still reaching $44 \%$, the mission-vision of the institution is almost $30 \%$, the work program is up to $18.7 \%$, and the structure is $12 \%$. License is fundamental in 
the establishment of childcare, as well as the completeness of the organization, along with work programs and performance standard operating procedures. According to this study, approximately $20 \%$ of child care still does not have organizational completeness. The completeness of the organization becomes very important to strengthen institutional services, both from the vision of the mission, as well as the structure. Clarity of institutional entity will result in work programs and standard operating procedures for childcare services. As for permits, child care permits are in the education local government office or under the ministry of education, whereas childcare for children under 2 years of age is more dominant in parenting. The existence of child care under the Educational Law needs to be further evaluated considering that parenting itself becomes the domain of the Ministry of Women Empowerment and Child Protection.

In general, the human resources of child care managers are adequate even though there must be improvements. The previous selection only reached $60 \%$. Such improvements include the need for selection for each individual who will be involved in the child care to check the child protection perspective and its track record. Professional support is very important for the supervision of children's development. In this study, the support of health workers, social workers, counselors, and psychologists is still $20 \%$ which means it still needs additions.

Child protection knowledge is not a priority in the child care staff training. Training on child protection perspectives has not reached $10 \%$. The childcare staff is working for children which requests understanding of child protection. Training on early childhood education is also only reached $28 \%$ and there is still child care who do not hold training. The caregiving training is only at $56 \%$ childcare. While the current certification of childcare staff is a baby sitter training without knowledge of child protection and child development. Training both concerning knowledge and parenting skills that contains the child protection perspective is the standard of training for the prospective child care team.

The need for child care is increasing because of the condition of working parents and it must be equivalent to the quality of service. In general, there is a fifth of child care that still needs to be improved. The ratio of caregivers and children who are not ideal as much as approximately $33 \%$ are under the age of 2 years. Despite this, children under the age of two still need high attention. In general, there are still approximately $20 \%$ of childcare that does not have good 
facilities in the availability of buildings, bedrooms and facilities, and waiting rooms.

Playing facilities is very important in the child development phase. The availability of indoor playground and toys are still at $12 \%$ that are not yet viable but already $80 \%$ which have an outdoor. Furthermore, in terms of toilets, most childcare has decent toilets, but in terms of storage of milk and food, there is still a quarter of daycare that does not have such a system. Providing food and breast milk is important to succeed in stunting prevention. While the big homework related to the security system in childcare because it only reached half of child care. In terms of service support, there are $20 \%$ of child care that needs to add nutritional and supplementary food support, religious education, sports, PAUD, services, and health. In general, childcare still needs to improve cooperation, parent and child counseling services, as well as interest talent tests to direct children's development.

\section{Conclusion}

The study found that the need for childcare due to the busyness of parents is quite high. However, there are still $44 \%$ of child care that has not been licensed which will influence the institutional quality of child care, including the vision of the agency's mission, structure, work programs, and operational standards procedures. In terms of human resources, the selection of all childcare staff is very important to ensure the track record and perspective of child protection. The support of professionals is very important such as health workers, social workers, counselors, and psychologists to improve the quality of child care services. Then, training to improve knowledge and skills with child protection perspectives should be conducted as a process of mainstreaming safe and child-friendly child care services.

In terms of services, approximately one-fifth of child care is still in need of service improvement. Among them are the ratio of caregivers and children under 2 years, building facilities, outdoor playgrounds, and childfriendly toys, storage of milk and food, nutritional and food support services, religious education, sports, PAUD, and health services. Child care also needs to improve cooperation and partnerships, counseling services, and support the development of child interest talents. Studies on the quality of services specifically and childcare studies with specific locations are very important in line with the increasing needs of child care. 


\section{References}

Azeharie, S., \& Khotimah, N. (2015). Pola komunikasi antarpribadi antara guru dan siswa di panti sosial taman penitipan anak melati Bengkulu. Pekommas, 18(3), 213-224. https://doi.org/10.30818/jpkm.2015.1180307

Bredekamp, S. (2017). Effective practices in early childhood education building a foundation. Pearson.

Clark, S., Kabiru, C. W., Laszlo, S., \& Muthuri, S. (2019). The impact of childcare on poor urban women's economic empowerment in Africa. Demography, 56(4), 1247-1272. https://doi.org/10.1007/s13524-019. 00793-3

Daniel, B., Wassell, S., Gilligan, R., \& Howe, D. (2010). Child development for child care and protection workers. Jessica Kingsley Publishers. https://search. proquest.com/legacydocview/EBC/677611?accountid=17242.

De Moura, M. L. S., Pessôa, L. F., De Oliveira Ramos, D., Mendes, D. M. L. F., Fioravanti-Bastos, A. C. M., \& Dias, L. B. T. (2014). Beliefs of mothers, nannies, grandmothers, and daycare providers concerning childcare. Paideia, 24(59), 341-349. https://doi.org/10.1590/198243272459201408

Delly, S., Zulminiarti, \& Hartati, S. (2018). Pelaksanaan standar operational prosedur di taman penitipan anak Hikari Kids Club Padang. Jurnal Ilmiah Pesona PAUD, 5(2), 109-120. DOI: https://doi.org/10.24036/103745

Dharmastuti, H. (2019). Kisah tragis balita tewas tanpa kepala di Samarinda hingga daycare ditutup. Detiknews. https://news.detik.com/ berita/d-4837213/kisah-tragis-balita-tewas-tanpa-kepala-di-samarindahingga-daycare-ditutup, access 20 January 2020.

Direktur Pembinaan PAUD, K. (2015). Norma, standar, prosedur, dan kriteria: Petunjuk teknis penyelenggaraan taman penitipan anak. Direktur Pembinaan PAUD. https://www.paud.id/juknis-tpa-taman-penitipan-anak-terbaru/

Dodds, P., Wyse, R., Jones, J., Wolfenden, L., Lecathelinais, C., Williams, A., Yoong, S. L., Finch, M., Nathan, N., Gillham, K., \& Wiggers, J. (2014). Validity of a measure to assess healthy eating and physical activity policies and practices in Australian childcare services. BMC Public Health, 14(1). https://doi.org/10.1186/1471-2458-14-572

Geoffroy, M. C., Côté, S. M., Parent, S., \& Séguin, J. R. (2006). Daycare 
attendance, stress, and mental health. Canadian Journal of Psychiatry, 51(9), 607-615. https://doi.org/10.1177/070674370605100909

Hastuti, D. (2015). Pengasuhan: Teori, prinsip, dan aplikasinya di Indonesia (1st ed.). IPB Press.

Hikmah, S. (2014). Optimalisasi perkembangan anak dalam day care. Sawwa, Jurnal Studi Gender, 9(2), 345-360. DOI: 10.21580/sa.v9i2.640

Hiryanto, H. (2007). Pemetaan tingkat pencapaian mutu program pendidikan anak usia dini (PAUD) di Propinsi DIY. Diklus, Jurnal Pendidikan Luar Sekolah, 6(11), 127-150.

Hurlock, E. B. (1996). Psikologi perkembangan. Erlangga.

Indrawati, I., \& Hadayani, S. P. (2014). Pola pengasuhan anak pada taman penitipan anak 'Aisyiyah wilayah Riau. Jurnal Online Mahasiswa (JOM) Bidang Ilmu Sosial dan Ilmu Politik, 1(2).

Krisnana, I., Rachmawati, P. D., \& Sholihah, M. (2016). Peran asah (3A) pengasuh dengan perkembangan bahasa anak usia toddler di taman penitipan anak. Jurnal Ners, 11(2), 240-245. http://dx.doi.org/10.20473/ jn.v11i2.2662

Kurniawaty, Y., Lestarina, N. N. W., \& Dewi, C. D. C. (2019). Program kemitraan masyarakat kelompok ibu pengasuh taman penitipan anak. Jurnal LeECOM (Leverage, Engagement, Empowerment of Community), 1(2), 81-92.

Kusno, A. (2014). Kesantunan linguistik kalimat imperatif oleh guru dan pengasuh kepada anak didik di taman penitipan anak (TPA) Sanggar Rubinha Samarinda. Jurnal Bahasa, Sastra, Dan Pembelajarannya, 4(2), 295-300. DOI: $10.20527 /$ jbsp.v4i2.3703

Kusumastuti, N. I. (2013). Fenomena taman penitipan anak bagi perempuan yang bekerja (Studi Kasus TPA Jaya Kartika Desa Ngringo, Kecamatan Jaten, Kabupaten Karanganyar). Sosialitas: Jurnal Ilmiah Pendidikan Sosiologi-Antropologi, 1-12.

Mardiastuti, A. (2019). Bayi tewas di daycare, pemilik-perawat Princess Childcare Bali ditangkap. Detik.News. https://news.detik.com/berita/d-4547379/ bayi-tewas-di-daycare-pemilik-perawat-princess-childcare-bali-ditangkap. access 21 December 2020.

Maulidina, A. I., \& Sumartinah, H. R. (2015). Pendekatan naratif dalam perancangan taman penitipan anak. Jurnal Sains dan Seni ITS, 4(2), 4750. DOI: $10.12962 / \mathrm{j} 23373520 . v 4 \mathrm{i} 2.12449$ 
Pranawati, R., Naswardi, \& Zulkarnaen, S. D. (2015). Kualitas pengasuhan anak Indonesia: Survei nasional dan telaah kebijakan pemenuhan hak pengasuhan anak di Indonesia. KPAI.

Putriana, R. D., Purnaweni, H., Publik, J. A., Profesor, J., Soedarto, H., Hukum, S., Semarang, T., \& Pos, K. (2016). Implementasi kebijakan pendidikan non formal di Kecamatan Tembalang. Journal Of Public Policy And Management Review, 5(4), 192-199. https://doi.org/10.14710/jppmr. v5i4.13555

Ralston, S. J. (2020). Distracted daycare and child welfare: An ethical analysis. Ethics and Social Welfare, 1-16. https://doi.org/10.1080/17496535.2020 .1730928

Simonsen, M. (2010). Employment price of high-quality daycare and female employment. The Scandinavian Journal of Economics, 112(3), 570-594. https://doi.org/10.HH/j.1467-9442.2010.01617.x

Sit, M. (2017). Psikologi perkembangan anak usia dini. Pranadamedia.

Staton, S., Pattinson, C., Smith, S., Pease, A., Blair, P., Young, J., Irvine, S., \& Thorpe, K. (2019). Observed compliance with safe sleeping guidelines in licensed childcare services. Archives of Disease in Childhood, 104(12), 1193-1197. https://doi.org/10.1136/archdischild-2019-317000

Sulistyasih, E. (2016). Relevansi antara kondisi penyelenggaraan dengan buku petunjuk teknis penyelenggaraan taman penitipan anak (TPA) di Kecamatan Bumiayu. INSANIA: Jurnal Pemikiran Alternatif Kependidikan, 21(2), 242-257. https://doi.org/10.24090/insania.v21i2.1417

Tucker, P., van Zandvoort, M. M., Burke, S. M., \& Irwin, J. D. (2011). Physical activity at daycare: Childcare providers' perspectives for improvements. Journal of Early Childhood Research, 9(3), 207-219. https://doi. org/10.1177/1476718X10389144

Uce, L. (2015). The golden age: Masa efektif merancang kualitas anak. Jurnal Pendidikan Anak BUnayya, 1(2), 77-92. https://doi.org/10.1007/978-3319-04840-6_5

Wijayanto, A. Y., \& Wulan Sari, D. (2019). Analysis of decision to work of female workers in Indonesia. Economics Development Analysis Journal, 8(3), 290-300. https://doi.org/10.15294/edaj.v8i3.29529 